\title{
ANALISIS PRAKTIK KERJA INDUSTRI TERHADAP PENGUASAAN SKILL SISWA DALAM MENGHADAPI DUNIA KERJA DI SMK NU BULULAWANG MALANG
}

\author{
Endah Andayani \\ Universitas Kanjuruhan Malang
}

\begin{abstract}
Abstrak
Prakerin merupakan pola pembelajaran dengan mendekatkan kesesuaian mutu tamatan dengan kemampuan kerja, pembelajaran ini berlangsung di dua tempat (di sekolah dan di industri). Di sekolah, para siswa diajarkan teori dan praktik, sedangkan di industri siswa dituntut mempraktikkannya. Dengan proses belajar seperti ini, siswa SMK akan memperoleh pengalaman yang sangat berharga dalam hal soft skills seperti kedisiplinan, kemampuan berkomunikasi, kejujuran, etos kerja yang tinggi, kreatifitas, kepemilikan jiwa entrepreneurship, dan kemampuan bekerjasama sebagai bekal memasuki bursa kerja; serta kompetensi teknis siswa (hard skill) dapat mengalami peningkatan saat siswa kembali belajar di sekolah. Tujuan penelitian untuk menganalisis pengaruh pelaksanan Praktik Kerja Industri terhadap penguasaan skill dalam menghadapi dunia kerja di SMK Nahdlatul Ulama Bululawang Kabupaten Malang. Penelitian termasuk penelitian korelasional untuk mencari pengaruh antara 2 (dua) variabel. Penelitian ini menggunakan data kuantitatif dengan rancangan penelitian survei. Sampel penelitian ini adalah seluruh siswa Kelas XII yang tersebar pada bidang studi akuntansi, administrasi perkantoran, dan teknik kendaraan ringan berjumlah 62 siswa. Teknik pengumpulan data berupa angket, yang sebelumnya dilakukan uji validitas dan reliabilitasnya. Teknik analisis data yang digunakan adalah Uji Analisis Regresi linier sederhana dengan berbatuan SPSS 20.0 for windows. Hasil pengujian hipotesis diketahui besarnya $t_{\text {hitung }}(5,866)>t_{\text {tabel }}(2,036)$ dan nilai Sig. $0,000<0,05$ maka Ho ditolak (Ha diterima) dengan demikian dapat dinyatakan bahwa variabel prakerin memiliki pengaruh yang signifikan terhadap variabel penguasaan skill siswa dalam menghadapi dunia kerja. Nilai koefisien Determinasi (R Square) sebesar 0,364 memiliki makna bahwa prakerin memberikan kontribusi sebesar 36,4\% terhadap perubahan penguasaan skill siswa dalam menghadapi dunia kerja, dengan kata lain sisanya sebesar $63,6 \%$ perubahan penguasaan skill siswa dalam menghadapi dunia kerja ditentukan oleh variabel lain yang tidak diteliti.
\end{abstract}

Kata Kunci: Prakerin, Penguasaan Skills

\begin{abstract}
Prakerin is learning patterns closer conformity with the quality of the graduates with the ability to work, learning takes place in two places (at school and in the industry). In school, students are taught the theory and practice, while the students are required to practice in the industry. With this kind of learning process, vocational students will gain invaluable experience in terms of soft skills such as discipline, communication skills, honesty, high work ethic, creativity, ownership entrepreneurial spirit, and ability to cooperate as a preparation to enter the labor market; as well as the technical competence of students (hard skills) can be increased when students return to school. The purpose of the conduct of studies to analyze the influence of the Prakerin to mastery skill in dealing with the world of work in SMK NU Bululawang Malang. Research including correlational research for influence between the two (2) variables. This study uses quantitative data with survey research design. The sample was all students of Class XII scattered on the field of study of accounting, administrative offices, and engineering light vehicles totaled 62 students. Data collection techniques in the form of a questionnaire, previously tested the validity and reliability. The data analysis technique used is simple linear regression analysis test with SPSS 20.0 for windows. Results of testing the hypothesis in mind the magnitude of $t$ count (5.866)> $t$ table (2,036) and the Sig. $0.000<0.05$ then Ho is rejected (Ha accepted) can thus be stated that prakerin variables have a significant effect on the variable student skill mastery in dealing with the world of work. The coefficient of determination ( $R$ Square) of 0.364 has a meaning that prakerin contributed $36.4 \%$ to changes in student skill mastery in dealing with the world of work, in other words, the balance of 63.6\% change in students' mastery of skills in dealing with the world of work is determined by variable others were not examined.
\end{abstract}

Keywords: Prakerin, Mastery Skills 


\section{PENDAHULUAN}

Pembelajaran dalam konteks kurikulum 2013 diyakini akan dapat terlaksana dengan baik dan mencapai tujuan yang diharapkan jika dikembangkan secara fundamental, terperinci, komprehensif, dan reflektif-evaluatif. Dengan demikian strategi pembelajarannya tidak dapat dilakukan untuk memenuhi kewajiban belaka, namun harus dilandasi dengan tekad yang besar untuk mengembangkan pembelajaran tepat guna dan tepat sasaran. Sementara itu perkembangan ilmu pengetahuan dan teknologi serta tuntutan globalisasi secara bersama-sama telah mengakibatkan persaingan yang semakin ketat dalam penyediaan sumber daya manusia yang unggul. Untuk dapat terus mempertahankan daya saingnya, sumber daya manusia yang ada dituntut untuk terus meningkatkan pengetahuan, keterampilan, sikap, dan kompetensinya. Seseorang yang memiliki tingkat kompetensi yang tinggi, akan cepat menyesuaikan perubahan yang ada di sekitarnya, termasuk dalam pergaulan, pekerjaan, maupun dalam perubahan situasi dan kondisi yang serba cepat.

Pada abad 21 dan diberlakukannya kerjasama Masyarakat Ekonomi Asean (MEA) tanggal 1 Januari 2016, tuntutan terhadap kompetensi berpikir semakin tinggi. Sejalan dengan konsep ini Marocco (2008) berpendapat bahwa pada abad ke-21 minimal ada 4 (empat) kompetensi belajar yang harus dikuasai peserta didik, yaitu; 1) kemampuan pemahaman yang tinggi; 2) kemampuan berpikir kritis; 3) kemampuan berkolaborasi; dan 4) kemampuan berkomunikasi. Mendukung pendapat ini Trilling \& Fadel (2009) menjelaskan bahwa keterampilan utama yang harus dimiliki dalam konteks abad ke-21 adalah: 1) keterampilan belajar dan berinovasi, yaitu keterampilan berkenaan dengan kemampuan berpikir kreatif dan kemampuan memecahkan masalah; 2) kemampuan berkomunikasi dan berkolaborasi; serta 3) kemampuan untuk berkreativitas dan berinovasi.

Sementara itu SMK yang selama ini di kenal sebagai sebagai sekolah Vocational yang diharapkan menghasilkan lulusan siap kerja sesuai motto dari SMK itu sendiri adalah "SMK BISA", maka dalam penyelenggaraan pendidikan harus "link and Macth" dengan kebutuhan dunia usaha atau dunia industri sebagai pasar kerja penerima lulusan. Artinya Sekolah Menengah Kejuruan (SMK) sebagai lembaga pendidikan formal yang memiliki pola pelatihan khusus untuk mengarahkan peserta didik agar menjadi lulusan yang siap terjun secara profesional dan ikut bergerak di dunia usaha atau perusahaan, sehingga diperlukan startegi pembelajaran yang tepat dan bermakna bagi komptensinya. Adapun yang dimaksud dengan strategi pemebelajaran menurut Orlich (2010) adalah perencanaan matang yang digunakan untuk melaksanakan sebuah pembelajaran. Strategi pembelajaran untuk mencapai tujuan penyelenggaraan karakteristik pendidikan di SMK adalah adanya pelaksanaan program pembelajaran Praktik Kerja Industri (Prakerin), sistem pembelajaran ini digunakan sebagai salah satu upaya untuk mempersiapkan tenagatenaga profesional yang siap pakai sesuai dengan kebutuhan pasar kerja, sehingga angkatan kerja dapat terserap.

Prakerin merupakan kegiatan yang dilakukan di sekolah dan Du/Di berupa pendidikan, pelatihan dan pembelajaran yang dilaksanakan di Dunia Usaha Atau Dunia Industri dalam upaya pendekatan ataupun untuk meningkatkan mutu lulusan dengan kompetensi siswa sesuai bidangnya dan juga menambah bekal pengalaman sebagai bekal 
mendatang guna memasuki dunia kerja yang semangkin kompetitif. Prosedur dalam pelaksanaannya dilakukan dalam waktu 4 (empat) bulan, siswa seakan-akan bekerja /magang di Du/Di untuk diajarkan tentang kehidupan di dunia kerja, diharapkan akan diperoleh tambahan skill yang bermanfaat bagi dirrinya. Penempatan Prakerin seharusnya sesuai bidang yang diminatinya (jurusan) di sekolah, sehingga dengan bekal dimilikinya ilmu pengetahuan dasar sesuai bidangnya diharapkan dalam pelaksanaan Praktek Kerja Industri tidak mengalami kendala. Tanpa diadakannya Prakerin siswa akan mengalami kesulitan atas jaringan kemitraan dan belum diketahuinya situasi dan kondisi lingkungan kerja. Selain itu pada nantinya perusahaan pencari tenaga kerja lulusan siswa SMK harus melakukan training terlebih dahulu kepada calon tenaga kerja, agar dapat bekerja secara profesional sesuai dengan standar perusahaan.

Secara umum visi dan misi sekolah SMK adalah untuk mempersiapkan peserta didik sebagi calon tenaga kerja yang memiliki kesiapan untuk memasuki dunia kerja. Keberadaan SMK dituntut untuk memenuhi kebutuhan masyarakat, yaitu kebutuhan tenaga kerja. Sehingga peserta didik dituntut untuk memiliki keterampilan dan sikap professional dalam bidangnya. Permendikbud No. 70 Tahun 2013 tentang kerangka dasar dan struktur kurikulum SMK/MA Kejuruan menjelaskan bahwa dalam penyempurnaan pola pikir Kurikulum 2013 dinyatakan bahwa: 1) pola pembelajaran dari model terisolasi menjadi pembelajaran secara jejaring (peserta didik dapat menuntut ilmu dari siapa saja dan dari mana saja yang dapat dihubungi serta diperoleh dari internet; 2) pola pikir sendiri menjadi belajar kelompok (berbasis tim); 3) pola pembelajaran berubah dari alat tunggal menjadi pembelajaran berbasis alat multi media; dan 4) pola pembelajaran pasif menjadi pembelajaran kritis. Lebih lanjut, sesuai dengan kurikulum SMK Dikmenjur (2008) tujuan pembelajaran siswa dapat: 1) Memasuki lapangan kerja dan mengembangkan sikap professional, (2) Mampu memilih karier, mampu berkompetensi dan mengembangkan diri, (3)Menjadi tenaga kerja tingkat menengah untuk mengisi kebutuhan dunia usaha/ dunia industri saat ini dan masa yang akan datang, (4) Menjadi tenaga kerja yang produktif, adaptif dan kreatif.

Sementara itu , hasil penelitian Andayani (2013) menyimpulkan bahwa Pelaksanaan Prakerin berpengaruh positif dan signifikan terhadap persepsi tentang dunia kerja pada siswa SMK, akan tetapi tidak berpengaruh signifikan terhadap sikap produktif pada siswa SMK di Kabupaten Malang. Sementara itu pengamatan di lapangan ditemukan masih banyak pelaksanaan Prakerin yang tidak sesuai antara bidang yang digelutinya di sekolah dan spesifikasi kerja di temapat magang, menjadi kerisauan peneliti lebih lanjut untuk melihat pengaruh Prakerin terhadap skill siswa. Berdsarkan hasil temuan ini dan memperhatikan tujuan SMK di atas, maka nilai tambah skill yang menjadi tujuan akhir pelaksanaan Prakerin menjadi fokus lain yang perlu mendapat perhatian dan pengkajian lebih mendalam. maka rumusan masalah yang ditetapkan adalah "Apakah benar-benar Prakerin dapat memberikan pengaruh yang signifikan bagi peningkatan skill siswa dalam menghadapi dunia kerja di SMK Nahdlatul Ulama' Bululawang Kabupaten Malang”. Tujuan penelitian ini untuk menganalisis pengaruh praktik kerja industri terhadap penguasaan skill siswa dalam menghadapi dunia kerja. 
Pendidikan Sistem Ganda atau dalam realisasinya disebut dengan Prakerin adalah suatu bentuk penyelenggaraan pendidikan keahlian profesional, yang memadukan secara sistematik dan sinkron antara program pendidikan di sekolah dan program kegiatan bekerja langsung di dunia kerja untuk mencapai suatu tingkat keahlian profesional. Dimana para siswa yang melaksanakan pendidikan tersebut diharapkan dapat menerapkan ilmu yang didapat dan sekaligus mempelajari dunia industri. Djoyonegoro, W (1999) menyatakan bahwa karakteristik pendidikan sistem ganda (Berbentuk Prakerin) sebagai salah satu bentuk penyelenggaraan pendidikan dan pelatihan kejuruan yang didukung oleh beberapa faktor yang menjadi komponennya antara lain: institusi pasangan, program pendidikan dan pelatihan bersama, kelembagaan kerjasama, nilai tambah, dan jaminan kelangsungan (sustainability). Lebih lanjut Djoyonegoro mengungkapkan bahwa konsep pendidikan sistem ganda mempunyai ciri-ciri, yakni: 1) program pendidikan sistem ganda menjadi program bersama, milik bersama, dan tanggung jawab bersama antara SMK dan industri pasangan, 2) dunia usaha/industri ikut serta dalam totalitas kegiatan SMK bahkan ikut serta dalam berbagai tingkatan proses pengambilan keputusan, mulai dari penentuan program studi, penyusunan kurikulum, pelaksanaan pendidikan, evaluasi dan sertifikasi, dan 3) pengintegrasian kegiatan belajar mengajar di sekolah dalam kegiatan praktik industri akan menghilangkan perbedaan standar nilai di sekolah, di industri, dan sekaligus mendekatkan supply dan demand ketenagakerjaan. Melalui kerjasama tersebut, dapat diperoleh output dan outcame yang optimal yaitu terciptanya sumberdaya manusia (SDM) yang berkualitas sesuai dengan kebutuhan masyarakat dan pasar kerja (Anwar, 2004).

Berdasar buku pedoman sekolah, yang dimaksud Praktik Kerja Industri (Prakerin) adalah suatu bentuk penyelenggaraan pendidikan keahlian profesional yang diperoleh melalui kegiatan di dalam dunia kerja terarah untuk mencapai tingkat profesional tertentu atau program bersama antara sekolah menengah kejuruan dengan dunia kerja/instansi yang menjadi mitra tersebut sehingga segala sesuatu yang menyangkut penyelenggaraan Prakerin perlu dibicarakan dan disepakati bersama. Manfaat Praktek Kerja Industri antara lain: 1) dapat menciptakan pandangan yang sesungguhnya tentang dunia kerja, 2) hasil belajar lebih bermakna sebagai bekal hidup dan pengembangan diri, 3) tenggang waktu (lead time) untuk mencapai tingkat profesional lebih singkat, dan 4) dapat memperoleh sesuatu pengalaman sesuai dengan teori yang diperoleh.

Perwujudan nyata dari PSG di SMK dinyatakan dalam bentuk Prakerin akan melibatkan siswa langsung bekerja di dunia usaha/industri agar siswa memiliki kompetensi yang sesuai dengan harapan dan tuntutan usaha/industri. Disamping itu juga diperoleh pengalaman kerja yang dapat digunakan untuk meningkatkan keahlian profesional, hal ini cukup beralasan mengingat dunia industri memerlukan tenaga kerja yang berkualitas dan ahli di bidangnya untuk mengoperasikan peralatan dan teknologi canggih, sehingga siswa SMK lebih siap pakai yang pada nantinya dapat mengurangi pemborosan dan lebih efisien, dimana pada tahap awal rekruitmen tenaga kerja dari SMK Du/Di tidak perlu memberikan latihan tambahan. Siswa selama mengikuti kegiatan prakerin tentunya akan mendapat pengalaman dan juga gambaran 
nyata terkait dengan tantangan dunia kerja yang pada nantinya akan dihadapi, sehingga siswa dapat menyiapkan skillnya yang dibutuhkan oleh dunia kerja.

Pakpahan (1995) berpendapat tujuan diselenggarakan pendidikan sistem ganda (Prakerin) adalah: 1) menghasilkan tenaga kerja yang bermutu yaitu tenaga kerja yang memiliki tingkat pengetahuan keterampilan dan etos kerja yang sesuai dengan tuntutan lapangan pekerjaan, 2) memperkokoh keterkaitan dan kesepadanan antara SMK dengan dunia usaha/industri, 3) meningkatkan efektifitas dan efisiensi program pendidikan dan pelatihan tenaga kerja bermutu, 4) meningkatkan efektifitas dan efisiensi proses pendidikan dan pelatihan tenaga kerja bermutu; dan 5) memberi pengakuan dan penghargaan terhadap pengalaman kerja sebagai bagian dari proses pendidikan. Sementara itu panduan Prakerin di SMK menjelaskan manfaat prakerin adalah sebagai berikut: 1) Menghasilkan tenaga kerja yang memiliki keahlian profesional, yaitu tenaga kerja yangmemiliki tingkat pengetahuan, keterampilan, dan semanagat kerja yang sesuai dengan tuntutan lapangan kerja; 2) Memperkokoh hubungan sekolah dengan Du/Di; 3) Meningkatkan efisiensi proses pendidikan dan pelatihan tenaga kerja yang berkualitas; 4) Memberi pengakuan dan penghargaan terhadap pengalaman kerja sebagai bagian dari proses pendidikan; dan 5) Menyiapkan SDM yang berkualitas sesuai dengan tuntutan zaman di era Teknologi Informasi dan Komunikasi.

Memasuki abad ke-21 banyak paradigma baru bermunculan dan memerlukan pertimbangan serta perhatian yang seksama. Lingkungan bisnis global akan menjadi semakin kompleks, dinamis, dan bermunculan berbagai konflik kepentingan. Hard skills seperti pemahaman tentang bidang pekerjaan fungsional atau area tertentu, tidak lagi mencukupi bagi seorang dalam meraih kesuksesan di dunia kerja. Pendidikan tradisional yang menekankan bahwa dalam bekerja, seseorang harus memiliki pengetahuan yang tinggi tentang bidang pekerjaannya, sekarang tidak lagi mencukupi. Kenyataannya masih sangat sedikit pandangan bahwa seorang pekerja harus memiliki soft skills.

Pembicaraan tentang soft skills tidak dapat dilepaskan dari pengertian kompetensi. Kompetensi dapat diartikan sebagai motif, sikap, keterampilan, pengetahuan, perilaku atau karakteristik pribadi lain yang penting untuk melaksanakan pekerjaan atau yang membedakan antara kinerja rata-rata dengan kinerja superior. Spencer and Spencer (dalam Idawati, 2004) mengemukakan kompetensi khususnya kompetensi kerja terdiri dari 5 komponen. Komponen tersebut adalah: (1) Knowledge, yaitu ilmu yang dimiliki individu dalam bidang pekerjaan atau area tertentu, (2) Skill, yaitu kemampuan untuk unjuk kerja fisik atau mental, (3) Self Concept, yaitu sikap individu, nilai-nilai yang dianut serta citra diri, (4) Traits yaitu karakteristik fisik dan respon yang konsisten atas situasi atau informasi tertentu, dan (5) Motives yaitu pemikiran atau niat dasar yang konstan yang mendorong individu untuk bertindak atau berperilaku tertentu.

Skill dan knowledge sering disebut hard skills, sedangkan self concept, traits dan motives disebut soft skills. Dalam menghadapi era global dengan akselerasi yang cepat maka diperlukan tenaga kerja yang tidak hanya mempunyai kemampuan bekerja dalam bidangnya (hard skills) namun juga sangat penting untuk menguasai kemampuan menghadapi perubahan serta memanfaatkan perubahan itu sendiri (soft skills). Oleh karena itu menjadi tantangan pendidikan 
untuk mengintegrasikan kedua macam komponen kompetensi tersebut secara terpadu dan tidak berat sebelah agar mampu menyiapkan SDM utuh yang memiliki kemampuan bekerja dan berkembang di masa depan.

John Oxenham (1984) dalam Wakhinuddin (2009) mengatakan bahwa apabila lulusan suatu sekolah tidak dapat dipekerjakan atau memperoleh pekerjaan yang sesuai dengan jenis dan tingkat pendidikan yang dimilikinya, sekolah atau guru-guru dianggap tidak berhasil dengan tugasnya. Hal ini berarti sekolah dianggap tidak mampu memenuhi kebutuhan masyarakat atau dunia kerja. Salah satu upaya untuk meningkatkan mutu dan relevansi pendidikan kejuruan adalah peningkatan keterkaitan dan keterpaduan (link and match) dalam implementasi Pendidikan Sistem Ganda (PSG). Lebih lanjut Wakhinuddin (2009) menyatakan bahwaa manfaat dari praktek industri adalah: 1) menumbuhkan perilaku kerja yang tinggi,

2) siswa mendapatkan kompetensi yang tidak didapatkan di sekolah, 3) siswa dapat memberikan konstribusi tenaga kerja di perusahaan, 4) memberi motivasi dan meningkatkan etos kerja siswa, 5) mempererat hubungan kerjasama antara sekolah dengan institusi pasangan, 6) memungkinkan untuk industri memberikan bantuan kepada sekolah (misal: magang guru, bantuan praktek), dan 7) sebagai promosi tamatan Sekolah Menengah Kejuruan.

Sementara itu menurut Elfindri (2010), Soft skill merupakan keterampilan dan kecakapan hidup, baik untuk sendiri, berkelompok, atau bermasyarakat, serta dengan Sang Pencipta. Dengan mempunyai soft skill membuat keberadaan seseorang akan semakin terasa di tengah masyara- kat. Keterampilan akan berko-munikasi, keterampilan emosional, keterampilan berbahasa, keterampilan berkelompok, memiliki etika dan moral, santun dan keterampilan spiritual. Semua sifat yang menyebabkan berfungsinya hard skill yang dimiliki soft skill dapat menentukan arah pemanfaatan hard skill. Jika seseorang memilikinya dengan baik, maka ilmu dan keterampilan yang dikuasainya dapat mendatangkan kesejahteraan dan kenyamana bagi pemiliknya dan lingkungan. Sebaliknya jika sesorang tidak memiliki soft skill yang baik, maka hard skill dapat membahayakan diri sendirri dan orang lain.

Sedangkan menurut Liza Marini (2011), soft skill merupakan komplemen dari hard skills. Jenis keterampilan ini merupakan bagian dari kecerdasan intelektual seseorang, dan sering dijadikan syarat untuk memperoleh jabatan atau pekerjaan tertentu. Dari definisi tersebut dapat dirumuskan bahwa pada dasarnya soft skill merupakan kemampuan yang sudah melekat pada diri seseorang, tetapi dapat dikembangkan dengan maksimal dan dibutuhkan dalam dunia pekerjaan sebagai pelengkap dari kemampuan hard skill. Soft skill sangatlah penting untuk diberikan kepada siswa SMK sebagai bekal mereka terjun ke dunia kerja dan industry. Elfindri dkk (2010) sebagaimana dikutip dalam buku pengembangan soft skill untuk pendidik, menyebutkan, di dalam praktek proses seleksi karyawan yang dilakukan oleh perusahaan pada umumnya melakukan filter berdasarkan pada aspek kemampuan berpikir logis dan analisis di tahap awal. Kemudian dilanjutkan dengan seleksi karakter dan sikap kerja, sementara pada proses seleksi akhir, baru dilakukan seleksi berdasarkan 
kemampuan teknis dan akademis calon pegawai tersebut.

Dewasa ini dunia kerja lebih cenderung melihat calon pekerja dari soft skillnya, tentu hal ini tidak mengesampingkan peranan hard skill sebagai kemampuan (kompetensi) atau keahlian pada bidang tertentu yang ditunjukkan melalui kesiapan kerja. Hard skill merupakan faktor penting dalam bekerja, namun keberhasilan seseorang dalam bekerja biasanya akan lebih ditentukan oleh faktor skillnya yang lebih baik. Temuan Sailah (2008) dalam mendapatkan fakta bahwa 10 kiat sukses dari 50 orang tersukses di Amerika tidak satupun yang menyebutkan pentingnya memiliki keterampilan teknis (hard skill) sebagai prasarat untuk sukses di dunia kerja. 50 orang tersukses di Amerika tersebut sepakat bahwa yang paling menentukan kesuksesan mereka bukanlah keterampilan teknis, melainkan kualitas diri yang termasuk dalam keterampilan lunak (soft skill). Dengan demikian bagi lulusan SMK yang memang dituntut untuk menguasai ketrampilan teknis (Hard skill), tentunya faktor keterampilan lunak (Soft skill) harus pula diperhatikan supaya kesuksesan yang didapatkan lebih optimal. Dengan demikian dapat disimpulkan bahwa dalam dunia kerja, soft skill menjadi sangat diperlukan keberadaannya dimulai dari proses perekrutan atau seleksi karyawan hingga tentunya pada saat bekerja. Keseimbangan antara kemampuan hard skill dan soft skill sangat diperlukan dalam dunia pekerjaan. Jika kemampuan hard skill saja yang dimiliki maka seseorang akan tersingkir oleh mereka yang mempunyai kemampuan soft skill.

\section{METODE PENELITIAN}

Jenis penelitian ini termasuk penelitian ex-post facto, karena variabel penelitian berhubungan dengan variabel yang telah terjadi dan tidak diberikan perlakuan terhadap variabel yang diteliti. Penelitian termasuk penelitian korelasional untuk mencari pengaruh antara 2 (dua) variabel. Penelitian ini menggunakan data kuantitatif dengan rancangan penelitian survei, dimana peneliti melakukan observasi dalam pengumpulan data serta mencatat data seperti apa adanya, serta menganalisis dan menafsirkan data tersebut, dengan teknis dengan mengambil sampel dari satu populasi dan memberikan kuesioner kepada responden untuk memperoleh data pada suatu saat tertentu dan menanyakan mengenai beberapa aspek terkait dengan variabel-variabel yang diteliti.

Secara rinci tujuan penelitian ini adalah untuk mengetahui pengaruh praktik kerja industri (prakerin) terhadap penguasaan skill siswa dalam menghadapi dunia kerja di SMK Nahdlatul Ulama' Bululawang Kabupaten Malang. Pengambilan sampel dalam penelitian ini dilakukan dengan cara pengambilan seluruh populasi atau sampel jenuh yaitu sejumlah 62 siswa pada siswa kelas XII yang baru saja menyelesaikan Prakerin selam 4 (empat) bulan. Teknik pengumpulan data menggunakan angket, yaitu dengan cara memberikan angket kepada responden untuk di isi sesuai dengan kondisinya. Penggunaan angket dalam penelitian ini untuk mengambil data penelitian tentang variabel prakerin (sebagai variabel bebas) dan penguasaan skill dalam menghadapi duni kerja (sebagai variabel terikat). Indikator untuk mengukur variabel Prakerin (X) adalah: 1) mutu pelaksanaan Prakerin; 2) Kompetensi pembimbing Prakerin; dan 3) kemanfaatan pelaksanaan 
Prakerin. Sedangkan untuk mengukur variabel penguasaan skill (Y) dalam menghadapi dunia kerja diukur melalui: 1) penguasaan hard skill; dan 2) penguasaan soft skill. Sebelum angket digunakan mengambil data penelitian terlebih dahulu di uji validitas dan realibilitasnya, supaya dapat diperoleh data yang akurat.

Adapun analisis yang digunakan adalah dengan menggunakan analisis regresi linier sederhana. Analisis regresi pada dasarnya bertujuan untuk mengetahui adakah pengaruh antara variabel bebas terhadap variabel terikat. Dalam penelitian ini juga menggunakan analisis deskriptif untuk memperoleh gambaran tentang variabel prakerin dan penguasaan skill dalam menghadapi dunia kerja. Pengujian hipotesis dilakukan dengan menggunakan uji $\mathrm{t}$ pada taraf $\alpha=0,05(5 \%)$. Kriteria pengujian hipotesis jika $t_{\text {hitung }}>t_{\text {tabel }}$ atau nilai Sig. $\leq$ 0,05 maka Ho ditolak (Ha diterima), Jika $\mathrm{t}_{\text {hitung }} \leq \mathrm{t}_{\text {tabel }}$ atau nilai Sig. $>0,05$ maka Ho diterima (Ha ditolak). Dalam proses penganalisisan digunakan program SPSS 20.0 for Windows.

\section{HASIL DAN PEMBAHASAN}

Model Summary merupakan output yang berisi ringkasan hasil pengujian model regresi atau menyajikan nilai koefisien korelasi ( $\mathrm{R}$ ) dan koefisien determinasi ( $\mathrm{R}$ Square). Nilai koefisien korelasi (R) merupakan nilai yang menunjukkan kuatnya hubungan antara variabel bebas (prakerin) dengan variabel terikat (penguasaan skill siswa dalam menghadapi dunia kerja), nilai koefisien korelasi 0,604 menunjukkan bahwa prakerin memiliki hubungan yang cukup kuat dengan penguasaan skill siswa dalam menghadapi dunia kerja.

Nilai koefisien Determinasi ( $\mathrm{R}$ Square) menunjukkan besarnya kontribusi prakerin terhadap penguasaan skill siswa dalam menghadapi dunia kerja, jadi nilai 0,364 memiliki makna bahwa prakerin memberikan kontribusi sebesar $36,4 \%$ terhadap perubahan penguasaan skill siswa dalam menghadapi dunia kerja, dengan kata lain sisanya sebesar $63,6 \%$ perubahan penguasaan skill siswa dalam menghadapi dunia kerja ditentukan oleh variabel lain yang tidak diteliti.

Berdasarkan hasil analisis data dapat disusun persamaan regresi sederhana $\mathrm{Y}=27,601+0,337$. Penjelasan dari persamaan regresi tersebut adalah sebagai berikut: 1) Nilai konstanta (a) sebesar 27,601 memiliki makna jika prakerin $(\mathrm{X})=0$ maka penguasaan skill siswa dalam menghadapi dunia kerja (Y) yang dicapai hanya $=27,601$. 2) Nilai koefisien regresi (b) sebesar 0,337 menunjukkan besarnya pengaruh prakerin (X) terhadap penguasaan skill siswa dalam menghadapi dunia kerja (Y), karena nilainya positif maka pengaruhnya searah, artinya jika prakerin (X) meningkat 1 satuan maka penguasaan skill siswa dalam menghadapi dunia kerja akan meningkat 0,337 satuan.

Hasil pengujian hipotesis diketahui besarnya $t_{\text {hitung }}=5,866$ dengan nilai Sig. 0,000 selanjutnya nilai t-hitung tersebut dibandingkan dengan t-tabel pada taraf $\alpha=$ 0,05 derajat bebas $(n-2)=62-2=60$ yaitu sebesar $=2,000$. Jadi $t_{\text {hitung }}(5,866)>t_{\text {tabel }}$ $(2,036)$ dan nilai Sig. $0,000<0,05$ maka Ho ditolak (Ha diterima) dengan demikian dapat dinyatakan bahwa variabel prakerin memiliki pengaruh yang signifikan terhadap variabel penguasaan skill siswa dalam menghadapi dunia kerja. Artinya Prakerin yang dilaksanakan oleh siswa SMK Bululawang Kabupaten Malang secara positif atau searah dapat mempengaruhi penguasaan skill siswa dalam menghadapi dunia kerja. Hal ini bisa dikatakan bahwa pelaksanakan prakerin 
sudah berkualitas, akan tetapi mutu penyelenggaraan tersebut kualitasnya masih harus lebih ditingkatkan, agar sesuai dengan tujuan dan target yang diharapkan baik sekolah maupun dunia industri sebagai pihak penerima tenaga kerja yang dalam rekruitmennya mengharapkan tenga kerja yang direkrut memiliki keterampilan hard skil dan soft skill yang memadai.

Berdasarkan data analisis penelitian di atas, maka dapat dijelaskan bebarapa hal yang penting terkait dengan variabel Prakerin (X) bahwa sub variabel: 1) Mutu pelaksanaan Prakerin: terdapat Panduan pelaksanaan Prakerin telah disusun dengan sangat baik dan lengkap baik, mampu sebagai pedoman dalam pelaksanaannya; Industri mitra pasangan sekolah dalam Prakerin memiliki fasilitas memadai yang sangat baik serta mampu mendukung keberhasilan program Prakerin; Pemberian Waktu pelaksanaan Prakerin terselenggara selama 4 (empat) bulan untuk memperoleh keterampilan yang memadai terlasana tepat waktu dan berjalan dengan sangat baik dan lancar; Tipe pekerjaan di Dunia Usaha/Dunia Industri atau Du/Di sudah sesuai dengan keahlian siswa hasil data menunjukkan hasil yang sangat baik; Sistem Pekerjaan yang dikerjakan siswa di Du/Di sudah tepat/sesuai dengan aturan kerja (instruksi kerja) yang ditetapkan dalam panduan; Tugas yang diberikan pada oleh Du/Di pada peserta Prakerin, sesuai dengan kompetensi/jurusan yang dimiliki; Kemampuan beradaptasi dengan $\mathrm{Du} / \mathrm{Di}$ dapat dilakukan dengn cepat, pada saat awal melaksanakan Prakerin; Du/Di memiliki pengelolaan yang baik sebagai tempat Prakerin, sehingga praktik berjalan dengan optimal sesuai tujuan; Peserta Prakerin dapat bekerja sama dengan orang lain, pada saat melaksanakan Prakerin; dan Prakerin memberikan tanggung jawab pribadi yang lebih besar secara personal dan dapat dipertanggungjawabkan oleh peserta dengan sangat baik. Hasil analisis selanjutnya tentang sub variabel: 2) kompetensi pembimbing Prakerin dapat dijelaskan bahwa: Pembimbingan dari sekolah dilaksanakan dengan efektif, yaitu minimal 2 minggu sekali, dari sisi kehadirannya dapat dilakukan lebih; Pembimbing selalu memberikan motivasi/dorongan untuk meningkatkan kemampuan dan keterampilan; Guru pembimbing Prakerin sangat kompeten dalam menjalankan tugas pemberian bimbingan; Instruktur di DU/DI yang diberikan berkompeten (menguasai materi pelatihan/praktik); Guru pembimbing Prakerin memberikan penilaian kinerja siswa di Prakerin secara kontinyu/ berkelanjutan; dan Guru Pembimbing mampu menyelesaikan persoalan dengan baik, setiap permasalahan yang disampaikan peserta Prakerin. Sedangkan sub variabel: 3) Kemanfaatan pelaksanaan prakerin, dapat dijelaskan bahwa: Penguasaan pengetahuan menjadi lebih mendalam setelah melaksanakan Prakerin; Prakerin telah memberikan pengalaman kerja yang berharga, dan sesuai dengan jurusan peserta Prakerin sebagai bekal untuk bekerja; peserta memiliki kemampuan komunikasi yang lebih baik setelah melaksanakan Prakerin; Prakerin memberikan kontribusi atas nilai-nilai positif (contoh: kerja keras, kerja tepat, kerja cepat) yang dibutuhkan oleh dunia kerja; Jenis praktik kerja yang diberikan pihak DU/DI disesuaikan dengan keterampilan/keahlian dasar yang dibutuhkan dalam dunia kerja; Kompetensi/keahlian semakin meningkat setelah melaksanakan Prakerin; Pelaksanaan Prakerin memberi manfaat pada saya supaya mampu mengantisipasi dampak perkembangan 
teknologi; Prakerin memberi dampak untuk senantiasa mampu merespon terhadap kemajuan teknologi; Memiliki daya adaptif/kemampuan menyesuaikan pada dunia kerja merupakan manfaat dalam melaksanakan Prakerin; Pelaksanaan

Prakerin telah menambah rasa percaya diri dan optimis karena membuat siswa memiliki pengalaman kerja; dan Kemampuan sosial peserta Prakerin untuk berinteraksi dengan orang lain menjadi lebih baik setelah melaksanakan Prakerin.

Berdasarkan data yang dijaring dan telah dianalisis menunjukkan bahwa variabel penguasaan skill dalam menghadapi duni kerja dapat dijelaskan bahwa: 1) Soft skil, ditemukan kemampuan berkomunikasi secara lisan dan tertulis peserta Prakerin menjadi sangat lebih baik; peserta belajar tentang pentingnya kejurjuran dalam bekerja dengan sangat baik dan konsisten; memiliki kemampuan bekerjasama dengan sangat bagus baik dengan teman sebaya maupun pihak pengelola Prakerin di $\mathrm{Du} / \mathrm{Di}$; belajar memiliki etor kerja yang tinggi dan pertanggungjawabannya, motivasi yang tinggi; memiliki kepercayaan diri yang lebih setelah melaksanakan Prakerin sehingga muncul kreativitas yang besar untuk mengembangkan nilai-nilai yang telah dipelajarinya; dan memiliki kemampuan entrepreneurship yang semakin berkembang. 2) Hard skill, telah menunjukkan bahwa peserta dapat menggunakan ilmu pengetahuan, teknologi, dan komunikasi menjadi sangat baik; kepemilikan keterampilan teknis yang sangat berkembang; dan kemampuan berpikir analisis yang dibutuhkan dalam dunia keraj juga menjadi sangat baik.

Hasil temuan ini selaras dengan kajian yang dilakukan Wagiran (2008) menunjukkan bahwa sepuluh besar kemam- puan utuh yang diharapkan dunia kerja/industri meliputi aspek: kejujuran, etos kerja, tanggungjawab, disiplin, menerapkan prinsip keselamatan kerja, inisiatif dan kreatifitas, kerjasama, penyesuaian diri, percaya diri, dan toleransi. Jelas bahwa aspek-aspek soft skills atau karakter kerja memiliki peran signifikan dalam menentukan keberhasilan suatu usaha/industri maupun kesuksesan karyawan itu sendiri. Oleh karenanya menjadi penting mendesain proses pendidikan kejuruan yang mampu menumbuhkan karakter kerja sebagai bagian integral kompetensi yang harus dimiliki lulusan. Mendukung temuan ini, berbagai penelitian (Kay, 2008; Soto, Zamroni, 2009; Samani, 2007, Wagiran 2008) menunjukkan bahwa soft skills memiliki peran strategis dalam menentukan kesuksesan seseorang di dalam pekerjaannya. Oleh karenanya integrasi hard skills dan soft skills dalam penyiapan tenaga kerja dengan berbagai upayanya termasuk pendidikan formal harus dilakukan. Namun demikian dalam kenyataannya banyak lembaga pendidikan yang belum menyadari pentingnya hal tersebut.

\section{KESIMPULAN DAN SARAN}

Kesimpulan penelitian ini adalah ada pengaruh pelaksanaan Prakerin terhadap penguasaan skill siswa dalam menghadapi dunia kerja. Skill ynag dimaksud merupakan integrasi hard skill dan soft skill yang dikembangkan secara bersama pada saat dilakukan Praktik Kerja Industri, sehingga akan memberikan kontribusi yang signifikan bagi pengembangan kompetensi/keahlian serta perangkat lunak seperti: kejujuran disiplin, komitmen, komunikasi, motivasi, kepercayaan diri, kreativitas, dan entrepreneurship bagi diri peserta didik. 
Saran yang diajukan adalah 1) kesesuaian jenis Du/Di dengan kompetensi awal (jurusan) yang dimiliki siswa harus diperhatikan, supaya pelaksanaan Prakerin akan bermakna bagi pengembangan kualitas keahlian siswa SMK; 2) pengelolaan Prakerin baik di sekolah maupun di Dunia Usaha/Dunia Industri hendaknya dipahami oleh pengelola, sehingga capaian pembelajaran yang ditetapkan dapat dicapai dengan tepat; dan 3) kompetensi pembimbing di sekolah dan instruktur di Dunia Usaha Dunia Industri harus paham dan menguasai proses pembimbingan, sehingga dapat menjaalankan tugasnya dengan benar.

\section{DAFTAR PUSTAKA}

Anwar, 2004. Pelaksanaan Program Pendidikan Sistem Ganda pada SMK di Kota Kendari. Jurnal Pendidikan dan Kebudayaan. Vol. 36, 13 - 17.

Andayani, Endah, 2013. Pengaruh Pengalaman Belajar Ekonomi, Praktik Kerja Industri, Literasi Ekonomi, dan Persepsi tentang Dunia Kerja terhadap Sikap Produktif Siswa (Studi pada SMK Bidang Keahlian Bisnis Manajemen di Kabupaten Malang). Disertasi, Program Studi Pendidikan Ekonomi, Pascasarjana, Universitas Negeri Malang.

Djoyonegoro, W. 1999. Pengembangan Sumber Daya Manusia melalui SMK. Jakarta: PT. Balai Pustaka (Persero).

Elfindri, 2010. Soft skill untuk Pendidik. Jakarta: Badause Media.

Idawati (2004) "Pemimpin bisnis yang sukses". Majalah Manajemen, MaretApril 2004.

Illah Sailah.2008. Pengembangan Soft Skills Di Perguruan Tinggi. Jakarta : Direktorat Jenderal Pendidikan Tinggi

Kay, K. (2008) "Preparing Every Child for the 21st Century". APEC EdNet - Xi'an Symposium Xi'an China, January 17.
Liza Marini, 2011. Program Pengembangan Soft skill Bagi Mahasiswa. Medan: Universitas Sumatera Utama.

Morocco, 2008. Supported Literacy for Adolescents: Transforming Teaching and Content Learning for The Twenty-First Century. San Fransisco: Jossey-Bass A Wiley Imprint.

Muchlas Samani (2007) Bahan Perkuliahan Program Doktor Pascasarjana UNY.

Orlich, D.C. 2010. Teaching Strategies: A Guide to Effective Instruction, Ninth Edition. Boston: Wadsworth, Cengage Learning.

Pakpahan, J. 1995. Pembinaan dan Pengembangan Pendidikan Sistem ganda pada Sekolah Menengah Kejuruan. Jakarta: Dikmenjur.

Trilling, B, \& Fadel, C. 2009. 21 st Century Skills: Learning for Life in Our Times. San Farncisco: Josssey-Bass A Wiley Imprint.

Wagiran, (2008a). Pengembangan Modul Pembelajaran Konstruktivistik Kontekstual Berbantuan Komputer (Modul Elektronik) Pada Matadiklat Pemesinan. Yogyakarta: Lembaga Penelitian UNY

Wagiran, .(2008b). Implementasi Alternative Assesment Model "Self Evaluation" untuk Meningkatkan Kualitas Perkuliahan Proses Pemesinan 3. Yogyakarta: Lembaga Penelitian UNY.

Wakhinuddin S. 2009. Penerapan PSG Melalui Praktek Kerja Industri Pada SMK. Juli 9 9:37 am

Zamroni. (2009). Kebijakan peningkatan mutu sekolah di Indonesia. Makalah. Disajikan dalam Seminar Nasional dalam Rangka Dies Natalis Ke-45 Universitas Negeri Yogyakarta di Auditorium Universitas Negeri Yogyakarta 25 April 2009

--------, Dikmenjur. 2008. Kurikulum SMK. Jakarta: Dikmenjur. -, Permendikbud No. 70 Tahun 2013 Tentang Kerangka Dasar da Struktur Kurikukulum SMK/MA Kejuruan. Jakarta. Kementerain Pendidikan dan Kebudayaan. 